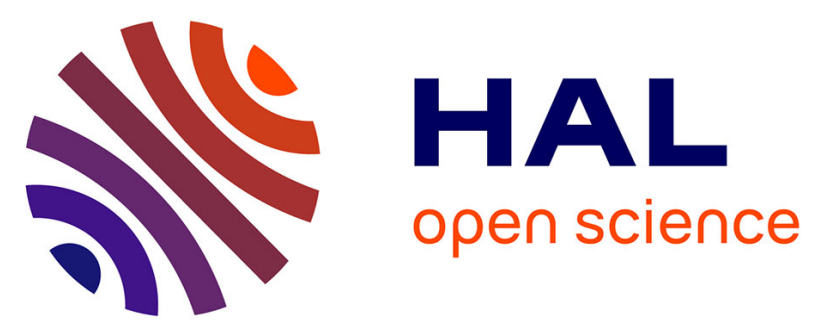

\title{
Improved short-term toxicity test protocol to assess metal tolerance in phototrophic periphyton: Toward standardization of PICT approaches
}

A.S. Lambert, S. Pesce, A. Foulquier, J. Gahou, Marina Coquery, A. Dabrin

\section{- To cite this version:}

A.S. Lambert, S. Pesce, A. Foulquier, J. Gahou, Marina Coquery, et al.. Improved short-term toxicity test protocol to assess metal tolerance in phototrophic periphyton: Toward standardization of PICT approaches. Environmental Science and Pollution Research, 2015, 22 (6), pp.4037-4045. 10.1007/s11356-014-3505-4 . hal-01355507

\section{HAL Id: hal-01355507 https://hal.science/hal-01355507}

Submitted on 23 Aug 2016

HAL is a multi-disciplinary open access archive for the deposit and dissemination of scientific research documents, whether they are published or not. The documents may come from teaching and research institutions in France or abroad, or from public or private research centers.
L'archive ouverte pluridisciplinaire HAL, est destinée au dépôt et à la diffusion de documents scientifiques de niveau recherche, publiés ou non, émanant des établissements d'enseignement et de recherche français ou étrangers, des laboratoires publics ou privés. 
1 Improved short-term toxicity test protocol to assess metal tolerance in phototrophic periphyton:

2 Toward standardization of PICT approaches

3

4 Anne Sophie Lambert ${ }^{1}$; Stéphane Pesce ${ }^{1}$; Arnaud Foulquier ${ }^{1,2}$; Josiane Gahou ${ }^{1}$; Marina Coquery ${ }^{1}$;

$5 \quad$ Aymeric Dabrin $^{1}$

6

7 1. Irstea, UR MALY, centre de Lyon-Villeurbanne, 5 rue de la Doua CS 70077, F-69626 Villeurbanne 8 cedex, France

9 2. INRA, UMR Carrtel, 75 av. de Corzent, BP 511. FR-74203 Thonon-les-Bains, France

Corresponding Author:

Anne-Sophie Lambert: Irstea, UR MALY, 5 rue de la Doua, CS70077, 69626 Villeurbanne Cedex,

Other e-mail addresses:

stephane.pesce@irstea.fr

$\underline{\text { arnaud.foulquier@irstea.fr }}$

19

josiane.gahou@irstea.fr

marina.coquery@irstea.fr 


\section{Abstract}

Pollution-induced community tolerance (PICT) approaches involve comparing tolerance levels of natural communities to a particular contaminant or a contaminant mixture using short-term toxicity tests performed under controlled conditions. However, results from toxicity tests can be modulated by various environmental and experimental conditions, raising questions about their reproducibility and comparability. In this context, the present study aimed to determine the influence of exposure duration, periphyton suspension concentration and periphyton maturation stage on the measurement of short-term effects of copper on phototrophic periphyton communities. Our results showed the very weak influence of exposure duration in the tested range (2-6h) on toxicity level, whereas periphyton biomass in the tested suspension (in terms of both chlorophyll $a$ concentrations and dry weight), proved a crucial determinant in toxicity assessment. Results also highlighted the potential tolerance increase with the periphyton maturation stage. This parameter conditioned the positive linear relationship between tolerance level and periphyton suspension concentration, leading to an increase in the linear regression slope with the maturation stage. This suggests that such a relationship is probably highly periphyton-dependent. Consequently, to enable data toxicity comparisons, an a priori normalization of the periphyton suspension biomass is necessary, and PICT approaches require the use, as much of possible, of periphyton with similar maturation stage. Finally, the present study clearly shows that a better standardization of PICT approaches could help to improve reproducibility. It could thus facilitate the comparison of tolerance levels measured in the same study (e.g. spatial and/or temporal and/or inter-treatment comparison) as well as the comparison obtained from different experimental and in situ research.

Keywords

Microbial ecotoxicology; Biofilm; PICT; Short-term toxicity tests; Metal. 


\section{Introduction}

The concept of pollution-induced community tolerance (PICT), first introduced by Blanck et al (1988), is an ecotoxicological tool that can help to characterize environmental status, since it takes into account the contamination history of the ecosystem at the community level (Tlili and Montuelle 2011). PICT is based on the fact that chronic exposure of a biological community to a toxicant will induce a succession of species resulting in a replacement of the sensitive species by more tolerant ones (Blanck 2002) and/or specific adaptation such as the establishment of mechanisms for detoxification, thus leading to an increased community tolerance to this toxicant (Tlili and Montuelle 2011). The approach uses the theoretical basis of toxicology (the dose-response model) to quantify community tolerance (Schmitt-Jansen et al. 2008), and can give an indication of past in situ exposure of the community to toxicants (Tlili and Montuelle 2011).

In principle, the PICT concept can be applied to terrestrial and aquatic ecosystems (Hjorth et al. 2006; Niklinska et al. 2006). Although, they can be applied with vertebrates (Knopper and Siciliano 2002) and invertebrates (Millward and Grant 2000), PICT approaches are used mainly for microbial communities such as bacteria (Boivin et al. 2005) and photosynthetic microorganisms (Dahl and Blanck 1996). Induced tolerance is observed by comparing the sensitivity of natural communities to a particular contaminant or contaminant mixture (Kim-Tiam et al. 2014), using short-term toxicity tests performed under controlled conditions. These tests are based on representative endpoints such as, photosynthetic efficiency (Dorigo et al. 2010; Tlili et al. 2010), respiration potential (Dorigo et al. 2010; Tlili et al. 2011) enzymatic activities (Fechner et al. 2012), and metabolic capacities (Boivin et al. 2005). Different studies have thus highlighted an increased tolerance of microbial communities to various substances such as metals and metalloids, and organic pesticides following chronic exposure to these toxicants in various ecosystems (see for reviews Blanck 2002; Imfeld and Vuilleumier 2012; Tlili and Montuelle 2011). In aquatic environments, metals including copper, zinc, lead, nickel, mercury, and cadmium have been particularly well-studied in PICT approaches, because of their abundance in surface waters and their potential toxicity to aquatic microbial communities (e.g. Gustavson et al. 1999; Soldo and Berha 2000; Barranguet et al. 2002; Serra and Guasch 2009). 
In lotic environments, the PICT approach is frequently applied on surface-associated microbial communities, called periphyton (or biofilm). Periphyton is a complex assembly of microbial communities (including microalgae, bacteria, fungi and heterotrophic protists) embedded in a polysaccharide and protein matrix. Since they are attached to natural surfaces, periphyton integrate the effects of multiple anthropogenic disturbances over extended periods of time, and have strong capacities to adapt to environmental changes (Sabater et al. 2007). Tolerance assessment of phototrophic periphyton communities (mainly composed of microalgae and cynaobacteria) is generally performed using photosynthesis as a functional parameter (Dahl and Blanck 1996; Bérard et al. 2003).

However, short-term effects of metals on photosynthesis can be modulated by various environmental and experimental conditions, and protocols used in toxicity test vary widely among studies, sometimes hindering comparison of results (Eklund and Kautsky 2003). For example, it has been shown that metal effects on microalgae depend not only on metal concentration, but also on cellular densities (Tobar et al. 1993). This biological parameter can modulate accumulation of metal on individual cells, thus modulating their exposure level (Steemann and Wium-Andersen 1970; Moreno-Garrido 1997). Moreno-Garrido et al. (2000) thus observed an increase in copper toxicity (i.e. a decrease in half effective concentration $\left(\mathrm{EC}_{50}\right.$ ) values) to marine microalgal species when their initial cellular density decreased. In the same way, Fechner et al. (2010) observed for heterotrophic periphyton communities an increase in metals $\mathrm{EC}_{50}$ values concomitantly with an increase in periphyton suspension concentrations (periphyton biomass used during the toxicity test). The literature reveals that exposure durations in toxicity tests with metals can vary widely among studies. For example, in the case of short-term toxicity tests to evaluate effects of copper on photosynthetic efficiency of periphyton, exposure duration (incubation duration) can be $2 \mathrm{~h}$ (Tlili et al. 2010; Lambert et al. 2012), $4 \mathrm{~h}$ (Guasch et al. 2004) or $6 \mathrm{~h}$ (Serra and Guasch 2009), but the influence of such differences on the obtained results is still sparsely documented. Since these parameters are rarely taken into account (or described) in studies using short-term toxicity tests, prior findings confirm the need for better standardization of toxicity tests for reproducibility and comparability of toxicity data, as previously stated (Soldo and 
Berha 2000; Eklund and Kautsky 2003; Fechner et al. 2010). It is now well accepted that PICT can serve as a powerful tool for in situ assessment of chronic effects of toxicants on periphyton communities (Pesce et al. 2010). This kind of approach raises question about the periphyton sampling procedure, which appears to be highly variable between studies, depending on the use of either natural (Dorigo et al. 2010) or artificial substrates, with fluctuating colonization durations (e.g from 2 weeks (Blanck and Dahl 1996) to 2 months (Pesce et al. 2010)). This notably raises the question of the influence of the maturation stage (growth stage) in tolerance assessment. Maturation processes include both species succession, which conditions the tolerance baseline of the community, and the building of a highly complicated structure that can form a protective layer (Extracellular Polymeric Substances), thereby influencing the level of exposure to toxicants (Ivorra et al. 2000; Gold et al. 2003a, 2003b).

Given this background, the main aim of our work was to help identify the most important parameters that must be considered to obtain reproducible and comparable results from short-term toxicity tests for metals on natural phototrophic periphyton communities.

Accordingly, we developed a microcosm approach aiming to accurately determine the influence of three main parameters on the significance and reproducibility of results obtained from short-term dose-response relationships for metals (as performed for tolerance determination in the PICT detection step). Copper was chosen as model compound because of its frequent occurrence in freshwater environments (Fechner et al. 2012) as well as its current use in PICT approaches. We thus focused on the influence of (i) periphyton suspension concentration, (ii) duration of exposure to copper, and (iii) periphyton maturation stage.

\section{Materials and Methods}

\subsection{Experimental setup and periphyton sampling procedure}

Microcosm experiments were carried out in three independent microcosms (glass, $40 \times 20 \times 25 \mathrm{~cm}$ ), incubated in thermoregulated tanks at $23{ }^{\circ} \mathrm{C}$ (polyethylene, $250 \mathrm{~L}, 121 \times 81 \times 33 \mathrm{~cm}$ ). One submersible pump (New Jet 800) was introduced in each microcosm to reproduce the water flow (water discharge 
$\sim 1.2 \mathrm{~L} / \mathrm{min}$ ), and three pumps were placed in the tank to homogenize water temperature. Highpressure sodium lamps were used to obtain a constant light intensity of 3500 lux $\left(42.7 \mu \mathrm{mol} \mathrm{m} \mathrm{s}^{-2} \mathrm{~s}^{-1}\right.$ under a $13 \mathrm{~h} / 11 \mathrm{~h}$ light/dark photoperiod. Artificial substrates (glass slides) were previously placed vertically at the surface in each microcosm to allow periphyton settlement. Microcosms were filled with untreated groundwater and a suspension of natural periphyton, collected on stones in April 2013 at the upstream reference site of the Morcille River (Beaujolais, Eastern France) with low $\mathrm{Cu}$ concentrations (dissolved concentrations lower than $0.9 \mu \mathrm{g} / \mathrm{L}$; see Montuelle et al. (2010) for details). Silica, nitrates and phosphates were added at concentrations of $15 \mathrm{mg} / \mathrm{L}, 8 \mathrm{mg} / \mathrm{L}$, and $0.2 \mathrm{mg} / \mathrm{L}$, respectively, to reach sampling site concentrations (Dorigo et al., 2010). Water was renewed weekly to avoid nutrient depletion. The experiment lasted 5 weeks. In order to obtain a periphyton suspension for short-term bioassays, two series of samples were taken from the microcosms, after 3 and 5 weeks of colonization, respectively. The periphyton was scraped from glass substrates collected in each microcosm, and suspended in a diluted equivalent mixture of demineralized water and mineral water (Evian, France) to obtain three replicates of periphyton suspension at $36 \mathrm{~cm}^{2} / \mathrm{mL}$.

\subsection{Short-term bioassays}

The same medium should be used for all toxicity tests, in order to avoid changes in metal bioavailability during metal toxicity testing (Blanck 2002, Blanck et al. 2003). Accordingly and to improve standardization an equivalent mixture of demineralized water and mineral water (Evian, France) was therefore used to prepare periphyton suspensions as well as $\mathrm{Cu}$ solutions. A semilogarithmic series of $\mathrm{Cu}$ concentrations was freshly prepared to obtain five $\mathrm{Cu}$ concentrations, ranging from about 0.32 to $32 \mathrm{mg} / \mathrm{L}$. $\mathrm{Cu}$ concentrations in each dilution were checked using inductively coupled plasma-mass spectrometry (ICP-MS X Series II, Thermo Electron).

The tolerance of phototrophic periphyton communities to $\mathrm{Cu}$ was assessed using photosynthetic efficiency as endpoint. Photosynthetic efficiency is based on the measurement of maximal quantum yield ( $\left.Y_{\text {II }}\right)$ of algae (Schreiber et al. 2002). It reflects the number of functional photosystems II (PSII), and therefore more generally the physiological state of the phototrophic communities (Tlili et al. 
162

163

164

165

166

167

168

169

170

171

172

173

174

175

2010). To assess this parameter, periphyton suspensions (1.8 $\mathrm{mL}$, see procedure below) were exposed to increasing concentrations of $\mathrm{Cu}(0.9 \mathrm{~mL})$ in a climatic chamber at $23{ }^{\circ} \mathrm{C}$ (temperature of microcosms during growth period) (MLR-350 Versatile Environmental Test Chamber, Sanyo) under artificial light (1400 lux). Samples were then kept for $30 \mathrm{~min}$ in a dark chamber and PSII quantum yield $(665 \mathrm{~nm})$ was determined using a PhytoPAM (pulse amplitude-modulated) fluorometer (Heinz Wals, Gmbh). For each sample replicate, four blanks and two analytical replicates were analyzed for each concentration. A single saturation pulse was applied to calculate the maximal quantum yield as $Y_{\mathrm{II}, 665 \mathrm{~nm}}=\left(F_{\mathrm{m}}-F_{0}\right) / F_{\mathrm{m}}$, where $F_{\mathrm{m}}$ is the maximum fluorescence after the saturation pulse, and $F_{0}$ is the steady state fluorescence.

Three variable parameters were assessed during the short-term toxicity tests: (i) periphyton biomass, (ii) exposure duration, and (ii) maturation stage. Given the predominance of phototrophic microorganisms in illuminated periphyton, we postulated that the estimation of the phototrophic biomass (based on chla concentrations) might give a relative estimation of the total biomass. The influence of periphyton biomass was thus tested using various periphyton suspension concentrations. Successive dilutions of the initial periphyton suspension were performed with the demineralized/mineral water mixture (see above) to obtain periphyton suspension concentrations ranging from about $400 \mu \mathrm{g}$ chla/L (dilution 4, i.e. D4) to about $7000 \mu \mathrm{g}$ chla/L (D1). These concentrations were estimated from chlorophylla (chla) measurement with the PhytoPAM fluorometer. This relative estimation of periphyton suspension biomass was then checked with 5-week periphyton by measuring total biomass (dry weight, DW) as described in Morin et al. (2010).

The influence of the duration of exposure to $\mathrm{Cu}$ was evaluated from toxicity tests after $2 \mathrm{~h}, 4 \mathrm{~h}$ and $6 \mathrm{~h}$ of incubation. The influence of the periphyton maturation stage was assessed by performing toxicity tests with periphyton retrieved after 3 and 5 weeks of development in the microcosms. 
189

190

191

192

193

194

195

196

197

198

199

200

201

202

203

204

205

206

207

208

209

210

211

212

\subsection{Statistical analysis}

The relationship between chla and periphyton DW was assessed using linear regression analysis. The analysis of results from short-term bioassay was conducted using functions from the 'drc' package (Ritz and Streibig 2005) in R version 2.15.0 (R Development Core Team 2012). Dose-response curves were fitted to the data using the four-parameter log-logistic model given by the formula:

response $=c+\frac{d-c}{1+\exp \{b \times(\log (\text { Dose })-\log (e))\}}$

where $b$ denotes the slope of the curve around $e$. Parameters $c$ and $d$ are the lower and upper limits of the curve, respectively, and $e$ denotes the $\mathrm{EC}_{50}$, the dose producing a response half-way between the upper and the lower limit. The response variable was expressed as the percentage of the yield of uncontaminated control assay. In addition, $\mathrm{EC}_{10}$, and $\mathrm{EC}_{50}$ were derived from each dose-response curve. Data from the three replicate bioassays were pooled to produce a single dose-response curve with the $\%$ inhibition of PSII activity as a function of $\mathrm{Cu}$ concentrations. Student $t$ tests were used to determine significant differences in $\mathrm{EC}_{x}$ between treatments using the selectivity index (SI) function from the 'drc' package. Linear regression analyses were performed to evaluate the relationship between $\mathrm{EC}_{x}$ and $\operatorname{chl} a$ concentrations. Analysis of covariance (ANCOVA) was used to determine whether the relationship differed between periphyton maturation stages.

\section{Results and discussion}

\subsection{Influence of tested parameters}

Assessment of short-term toxicity of $\mathrm{Cu}$ to 3 -week periphyton photosynthetic efficiency showed a positive correlation between $\mathrm{EC}_{x}$ and periphyton suspension concentration, whatever the exposure duration (Table 1; Fig. 2). For example, after $6 \mathrm{~h}$ of incubation, $\mathrm{EC}_{50}$ increased about 14-fold between the most diluted periphyton suspension (D4, mean $\mathrm{EC}_{50}=0.09 \mathrm{mg} / \mathrm{L}$ ) and the least $(\mathrm{D} 1$, mean $\left.\mathrm{EC}_{50}=1.23 \mathrm{mg} / \mathrm{L}\right)$, which was characterized by chl $a$ concentrations $(6980 \mu \mathrm{g} / \mathrm{L})$ about 17 times 
higher than chla concentrations in D4 samples $(420 \mu \mathrm{g} / \mathrm{L})$. Also, the positive linear relationship $(p<0.05)$ was observed between chla concentrations in periphyton suspension and both $\mathrm{EC}_{50}$ and $\mathrm{EC}_{10}$ values (Fig. 2), whatever the periphyton maturation stage (3 and 5 weeks). A significant linear relationship $(p<0.05)$ was also obtained when comparing $\mathrm{EC}_{x}$ and total biomass (based on DW measurement), which was determined for the 5-week periphyton (data not shown). These results thus highlight the marked influence of the periphyton suspension concentration on tolerance measurement in toxicity tests. Performing short-term toxicity tests based on $\beta$-glucosidase enzymatic activity, Fechner et al. (2010) also observed an increase in $\mathrm{EC}_{50}$ values with an increase in concentration of periphyton suspensions. Ahuja et al. (1999) showed that increasing biomass concentration from 0.04 to $0.20 \mathrm{gDW} / \mathrm{L}$ decreased the level of metal binding per unit cell mass. In addition, according to Monteiro and Castro (2012), the effective surface area available for sorption, and the average distance between available adsorption sites, is reduced by partial aggregation of biomass at high biomass. These studies therefore suggest that the observed increase in tolerance to $\mathrm{Cu}$ at higher periphyton suspension concentration in the present study is due, at least partially, to a decrease in periphyton exposure to $\mathrm{Cu}$ during toxicity testing.

We also tested, with a 3-week periphyton, and for the various periphyton suspension concentrations, the influence of exposure duration $(2,4$ and $6 \mathrm{~h})$ to $\mathrm{Cu}$ on the tolerance measurement (Table1). Despite the increase in $\mathrm{EC}_{50}$ values with the increase in periphyton suspension concentration used in the toxicity test, no significant difference was observed for this parameter between the three tested exposure durations ( $2 \mathrm{~h}, 4 \mathrm{~h}$ and $6 \mathrm{~h}$ of incubation), whatever the periphyton dilution (D1 to D4). Effects of exposure duration on $\mathrm{EC}_{10}$ were also imperceptible or very limited, the only significant differences being observed between $4 \mathrm{~h}$ and $6 \mathrm{~h}$ of incubation for the periphyton suspension concentration D3, with values of the same order of magnitude ( 0.01 to $0.05 \mathrm{mg} / \mathrm{L}$ ). Within the range of test conditions in the present study $(2-6 \mathrm{~h})$, exposure duration had a negligible influence on the measurement of tolerance to $\mathrm{Cu}$ whatever the periphyton suspension concentrations. Tlili et al (2011) also observed that the dose-response curve did not change with longer exposure to copper $(3,4$ and 6h) when performing toxicity tests based on respiration, and they opted for the shorter exposure time. 
In our toxicity tests based on photosynthetic efficiency, a $2 \mathrm{~h}$ incubation seems sufficient for the cellular uptake of $\mathrm{Cu}$. Thus we decided to perform the following short-term toxicity tests (toxicity test with a 5-week periphyton) using $2 \mathrm{~h}$ of incubation as previously used by Tlili et al. (2010).

The third parameter tested was the influence of the maturation stage of the periphyton. $\mathrm{EC}_{50}$ and $\mathrm{EC}_{10}$ were determined from short-term toxicity tests, after $2 \mathrm{~h}$ of incubation, performed with 3 - and 5-week periphyton (Fig 2), considering different periphyton suspension concentrations (D4 to D1). At equal periphyton suspension concentration, and despite the variability between replicates, $\mathrm{EC}_{x}$ mean values were higher for 5-week periphyton than for 3-week periphyton $\left(\mathrm{EC}_{50}\right.$ : $\mathrm{D} 3 p<0.05 ; \mathrm{EC}_{10}$ : D1, D3 $p<0.05$, Fig 2).

In the present study, phototrophic periphyton had a greater tolerance to $\mathrm{Cu}$ at higher maturation stage, highlighting the potential variability of tolerance levels with periphyton maturation stage during toxicity tests. This result is consistent with the study of Ivorra et al. (2000), who showed a variation in the effects of metal exposure ( $\mathrm{Zn}$ and $\mathrm{Cd}$ ) with the developmental stage of the periphyton. They observed that mature periphyton were more resistant to metals, even without a history of pre-exposure. A resistance to Cd was also observed on mature phototrophic periphyton by Duong et al. (2010). Studying $\mathrm{Cu}$ effects, Tien and Chen (2013) explained the decreased metal accumulation in a more mature periphyton by a decrease in metal-binding capacity thus probably reducing the exposure of periphyton communities. These results could explain our findings concerning the increased tolerance to $\mathrm{Cu}$ at higher periphyton maturation stage during toxicity tests. In addition, although the relationship between $\mathrm{EC}_{x}$ values and chla concentrations (used as a proxy of periphyton suspension concentration for the toxicity test) was significant $(p<0.05)$ whatever the age of the periphyton, it was modulated according to the sample considered ( 3 or 5 weeks; Fig. 1) as shown by the significant difference in slope values $(p<0.05)$. The slope value of the linear relationship obtained with a 5 weeks periphyton was significantly higher than that obtained with a 3-week periphyton $(p<0.05)$, thus suggesting that at higher biomass, the protective effect is stronger for a periphyton at a later maturation stage. 
The results of this study argue for more standardized procedures adapted to PICT approaches. Among the different parameters tested, exposure duration seems to have the least influence on tolerance measurement. However, short-term toxicity tests are generally performed in small water volumes with limited periphyton quantities, which can quickly induce significant changes in microbial community because of the "bottle effect". This was first observed by Schelske (1984), who showed that effects of confinement on the structure of phytoplankton communities could outweigh toxicant effects. However, PICT is based on the fact that a chronic exposure of communities to a toxicant can induce shift in species composition, thus leading to an increase in tolerance capacities. Indeed, it is better to limit as much as possible community changes during toxicity testing (i.e. PICT detection). Accordingly, we recommend short exposure (i.e. 2 h). Based on literature analysis, this duration seems sufficient to assess short-term effects of other metals, such as zinc, nickel and silver, on phototrophic periphyton (Soldo and Behra 2000)

By contrast, we showed that periphyton biomass in the tested suspension (in terms of both chla concentrations and DW) is a crucial determinant in toxicity assessment because of its significant influence on tolerance level. Consequently, this parameter should be standardized to obtain comparable results between studies. Previous authors suggested using an a posteriori normalization of toxicity data, based on periphyton biomass (Soldo and Behra 2000; Fechner et al. 2010; Lambert et al. 2012). In these studies, toxicity data were normalized by dividing $\mathrm{EC}_{x}$ by the periphyton dry weight (expressed in grams of dry matter per liter) (Fechner et al. 2010) or by the chla concentration in the periphyton suspension (Soldo and Behra 2000; Lambert et al. 2012). However, our results revealed that the linear relationship observed between $\mathrm{EC}_{x}$ and periphyton suspension concentration (expressed as chla or DW) depends on periphyton maturation stage, as shown by the significant difference in the slopes of the relationship observed respectively with 3-week and 5-week periphyton (ANCOVA $p<0.05$, Fig 1). Accordingly, an a posteriori normalization could sometimes be inappropriate since periphyton structure continuously evolves, and can differ widely according to numerous biotic and abiotic parameters. More generally, and independently of the importance of the maturation stage, our 
results suggest that the relationship between $\mathrm{EC}_{x}$ and chl $a$ is probably highly periphyton-dependent. Hence in order to take into account the differences between sampling sites or between sampling periods and thus enable data toxicity comparisons, an a priori normalization of the periphyton suspension biomass is advocated.

However, one challenge of such an a priori normalization resides in the fact that toxicity tests must be performed with fresh periphyton, rapidly after sample collection. As DW measurement is timeconsuming because of methodological constraints, the use of chla concentrations, as a proxy of biomass, could be a good alternative, because of the possible use of PhytoPam (or other fluorimetric measurement), which allows an immediate estimation of chla concentrations. In the present study, this alternative appears methodologically robust as shown by the close positive linear relationship between DW and chl $a$ obtained in the various dilutions performed with the 5-week periphyton $(p<0.001$, Fig. 3). Hence it would be of interest to check whether this relationship between DW and chla extends to periphyton with higher abundances of heterotrophic microorganisms. It can be argued that such $a$ priori normalization would require using disrupted periphyton (suspension periphyton). The use of disrupted or intact periphyton in short-term toxicity assessment is a recurrent debate, and it is known that the periphyton structure (i.e. suspended or attached) influences response to acute metal exposure. Given the protective role of the periphyton matrix, which limits the penetration of toxicants, undisrupted periphyton communities are generally more tolerant to metals than suspended periphyton communities (Barranguet et al. 2000; Guasch et al. 2003). Nevertheless, the high resistance of thick periphyton to metals can be mainly related to the physical structure of the assemblage, independently of species composition and their intrinsic tolerance properties (Barranguet et al. 2000). This can introduce a potential source of bias in PICT approaches which aim at evaluating changes in tolerance at the community level. Furthermore, since a priori normalization of periphyton biomass on attached assemblages appears impossible, our results offer new arguments in support of using disrupted periphyton, as is the case in many PICT studies (e.g. Soldo and Behra 2000; Dorigo et al. 2010; Tlili et al. 2010). According to the $\mathrm{EC}_{x}$ values obtained, it seems preferable to consider low periphyton biomass (chla $<3000 \mu \mathrm{g} / \mathrm{L}$ or DW $<0.4 \mathrm{mg} / \mathrm{mL}$ in our case) in order to reduce the variability 
observed between replicates, because of the difficulty in homogenizing disrupting periphyton samples at high suspension concentrations.

We also confirmed in the present study the importance of the maturation stage of the periphyton used for toxicity tests. This raises particular concerns when using PICT approaches in natural environments with periphyton collected on natural substrates, without knowledge about the colonization duration. One possible alternative is the use of artificial substrates, as chosen by many authors (Guasch et al. 2003; Dorigo et al. 2010; Morin et al. 2010), despite the well-known biases due to the fact that artificial substrates do not perfectly reflect natural substrates (Peterson et al. 1989; Potapova et al. 2005). This alternative is of particular interest in PICT studies designed to assess spatial and/or temporal changes in tolerance. In this context, we note that it could be of interest to define the recommended colonization time before a periphyton can be used in toxicity tests. However, and given the fact that periphyton maturation greatly depends on various environmental factors and is strongly site-dependent, this parameter is probably one of the most difficult to define with a view to a better standardization of PICT approaches.

In addition to parameters considered in our study, it would be of interest to further identify and test other factors that could significantly influence results and conclusions from PICT studies (e.g. temperature incubation or light intensity).

Acknowledgments We thank ATT for English-language editing. We also thank Bernard Motte, Christophe Rosy and Bernadette Volat for technical support, and Irstea's Water Chemistry Laboratory (LAMA). This study was partially funded by the French National Research Agency (project ANRCESA-Potomac 2012-2015). 


\section{References}

Ahuja P, Gupta R, Saxena RK (1999) Zn ${ }^{2+}$ biosorption by Oscillatoria anguistissima. Process Biochem 34: $77-85$

Barranguet C, Charantoni E, Plans M, Admiraal W (2000) Short-term response of monospecific and natural algal biofilms to copper exposure. European Journal of Phycology 35: 397-406

Barranguet C, Plans M, van der Grinten E, Sinke JJ, Admiraal W (2002) Development of photosynthetic periphyton affected by dissolved and sorbed copper in a eutrophic river. Environ Toxicol Chem 21: 1955-1965

Berard A, Dorigo U, Mercier I, Becker-van Slooten K, Grandjean D, Leboulanger C (2003) Comparison of the ecotoxicological impact of the triazines Irgarol 1051 and atrazine on microalgal cultures and natural microalgal communities in Lake Geneva. Chemosphere 53: 935944

Blanck H (2002) A critical review of procedures and approaches used for assessing pollution-induced community tolerance (PICT) in biotic communities. Hum Ecol Risk Assess 8: 1003-1034

Blanck H, Admiraal W, Cleven RFMJ, Guasch H, van den Hoop MAGT, Ivorra N, Nystrom B, Paulsson M, Petterson RP, Sabater S, Tubbing GMJ (2003) Variability in zinc tolerance, measured as incorporation of radio-labeled carbon dioxide and thymidine, in periphyton communities sampled from 15 European river stretches. Arch Environ Con Tox 44: 17-29

Blanck H, Dahl B (1996) Pollution-induced community tolerance (PICT) in marine periphyton in a gradient of tri-n-butyltin (TBT) contamination. Aquat Toxicol 3: 59-77

Blanck H, Wängberg SA, Molander S (1988). Pollution-induced community tolerance - A new ecotoxicological tool. In: Cairns J, Pratt JR (eds) Functional testing of aquatic biota for estimating hazards of chemicals, Vol STP 988. American Society for Testing and Materials, Philadelphia: 219-230 
Boivin MY, Massieux B, Breure AM, van den Ende FP, Greve GD, Rutgers M, Admiraal W (2005) Effects of copper and temperature on aquatic bacterial communities. Aquat Toxicol 71: 345-356

Dahl B, Blanck H (1996) Toxic effects of the antifouling agent Irgarol 1051 on periphyton communities in coastal water microcosms. Mar Pollut Bull 32: 342-350

Dorigo U, Bérard A, Rimet F, Bouchez A, Montuelle B (2010) In situ assessment of periphyton recovery in a river contaminated by pesticides. Aquat Toxicol 98: 396-406

Duong TT, Morin S, Coste M, Herlory O, Feurtet-Mazel A, Boudou A (2010) Experimental toxicity and bioaccumulation of cadmium in freshwater periphytic diatoms in relation with periphyton maturity. Sci Total Environ 408: 552-562

Eklund BT, Kautsky L (2003) Review on toxicity testing with marine macroalgae and the need for method standardization - exemplified with copper and phenol. Mar Pollut Bull 46: 171-181

Fechner LC, Dufour M, Gourlay-France C (2012) Pollution-induced community tolerance of freshwater periphyton: measuring heterotrophic tolerance to $\mathrm{Pb}$ using an enzymatic toxicity test. Ecotoxicology 21: 2123-2131

Fechner LC, Gourlay-France C, Uher E, Tusseau-Vuillemin MH (2010) Adapting an enzymatic toxicity test to allow comparative evaluation of natural freshwater periphyton' tolerance to metals. Ecotoxicology 19: 1302-1311

Gold C, Feurtet-Mazel A, Coste M, Boudou A (2003a) Effects of cadmium stress on periphytic diatom communities in indoor artificial streams. Freshwater Biol 48: 316-328

Gold C, Feurtet-Mazel A, Coste M, Boudou A (2003b) Impacts of Cd and Zn on the development of periphytic diatom communities in artificial streams located along a river pollution gradient. Arch Environ Con Tox 44: 189-197

Guasch H, Admiraal W, Sabater S (2003) Contrasting effects of organic and inorganic toxicants on freshwater periphyton. Aquat Toxicol 64: 165-175 
Guasch H, Navarro E, Serra A, Sabater S (2004) Phosphate limitation influences the sensitivity to copper in periphytic algae. Freshwater Biol 49: 463-473

Gustavson K, Petersen S, Pedersen B, Stuer-Lauridsen F, Pedersen S, Wangberg SA (1999) PollutionInduced Community Tolerance (PICT) in coastal phytoplankton communities exposure to copper. Hydrobiologia 416: 125-138

Hjorth M, Dahllof I, Forbes VE (2006) Effects on the function of three trophic levels in marine plankton communities under stress from the antifouling compound zinc pyrithione. Aquat Toxicol 77: 105-115

Imfeld G, Vuilleumier S (2012) Measuring the effects of pesticides on bacterial communities in soil: a critical review. European Journal of Soil Biology 49: 22-30

Ivorra N, Bremer S, Guasch H, Kraak MHS, Admiraal W (2000) Differences in the sensitivity of benthic microalgae to $\mathrm{Zn}$ and $\mathrm{Cd}$ regarding periphyton development and exposure history. Environ Toxicol Chem 19: 1332-1339

Kim Tiam S, Morin S, Pesce S, Feurtet-Mazel A, Moreira A, Gonzalez P, Mazzella N (2014) Environmental effects of realistic pesticide mixtures on natural periphyton communities with different exposure histories. Sci Total Environ: 473, 496-506

Knopper LD, Siciliano SD (2002) A Hypothetical Application of the Pollution-Induced Community Tolerance Concept in Megafaunal Communities Found at Contaminated Sites. Human and Ecological Risk Assessment 8: 1057-1066

Lambert AS, Morin S, Artigas J, Volat B, Coquery M, Neyra M, Pesce S (2012) Structural and functional recovery of microbial periphyton after a decrease in copper exposure: Influence of the presence of pristine communities. Aquat Toxicol 109: 118-126 
Millward RN, Grant A (2000) Pollution-induced tolerance to copper of nematode communities in the severely contaminated restronguet creek and adjacent estuaries, Cornwall, United Kingdom. Environmental Toxicology and Chemistry 19: 454-461

Monteiro CM, Castro PML, Malcata FX (2012) Metal uptake by microalgae: Underlying mechanisms and practical applications. Biotechnol Progr 28: 299-311

Montuelle B, Dorigo U, Berard A, Volat B, Bouchez A, Tlili A, Gouy V, Pesce S (2010) The periphyton as a multimetric bioindicator for assessing the impact of land use on rivers: an overview of the ArdiSres-Morcille experimental watershed (France). Hydrobiologia 657: 123141

Moreno-Garrido I, González-Delvalle M, Lubián LM (1997) Acumulación de cobre en microalgas usadas en acuicultura. Actas del VII Seminario de Químmica Marina, Servicio de Publicaciones de la Universidad de Cádiz : 279-286.

Moreno-Garrido I, Lubián LM, Soares AMVM (2000) Influence of cellular density on determination of EC50 in microalgal growth inhibition tests. Ecotox Environ Safe 47: 112-116

Morin S, Pesce S, Tlili A, Coste M, Montuelle B (2010): Recovery potential of periphytic communities in a river impacted by a vineyard watershed. Ecological Indicators 10, 419-426

Niklinska M, Chodak M, Laskowski R (2006) Pollution-induced community tolerance of microorganisms from forest soil organic layers polluted with $\mathrm{Zn}$ or $\mathrm{Cu}$. Appl Soil Ecol 32: 265272

Pesce S, Margoum C, Montuelle B (2010) In situ relationships between spatio-temporal variations in diuron concentrations and phototrophic periphyton tolerance in a contaminated river. Water Res 44: 1941-1949

Peterson CG, Stevenson RJ (1989): Substratum conditioning and diatom colonization in different current regimes. J Phycol 25: 790-793 
Potapova M, Charles DF (2005): Choice of substrate in algae-based water-quality assessment. J N Am Benthol Soc 24: 415-427

Ritz C, Streibig JC (2005): Bioassay analysis using R. J Stat Softw 12: 1-22

R Development Core Team (2012) R: a language and environment for statistical computing. R Foundation for Statistical Computing: Vienna. http://www.R-project.org

Sabater S, Guasch H, Ricart M, Romani A, Vidal G, Klunder C, Schmitt-Jansen M (2007): Monitoring the effect of chemicals on biological communities. The periphyton as an interface. Anal Bioanal Chem 387: 1425-1434

Schelske C (1984) In situ and natural phytoplankton assemblage bioassays. Algae as Ecological Indicators, Academic Press, New York 1984: 15-47, 6 fig, 106 ref.

Schmitt-Jansen M, Veit U, Dudel G, Altenburger R (2008): An ecological perspective in aquatic ecotoxicology: Approaches and challenges. Basic Appl Ecol 9: 337-345

Schreiber U, Muller JF, Haugg A, Gademann R (2002): New type of dual-channel PAM chlorophyll fluorometer for highly sensitive water toxicity biotests. Photosynth Res 74: 317-330

Serra A, Guasch H (2009) Effects of chronic copper exposure on fluvial systems: Linking structural and physiological changes of fluvial periphyton with the in-stream copper retention. Sci Total Environ 407: 5274-5282

Soldo D, Behra R (2000) Long-term effects of copper on the structure of freshwater periphyton communities and their tolerance to copper, zinc, nickel and silver. Aquat Toxicol 47: 181-189

Steemann NE, Wium-Andersen S (1970) Copper ions as poison in the sea and in freshwater. Mar. Biol 6: $93-97$

Tien CJ, Chen CS (2013) Patterns of metal accumulation by natural river periphyton during their growth and seasonal succession. Arch Environ Con Tox 64: 605-616 
Tlili A, Berard A, Roulier JL, Volat B, Montuelle B (2010) PO43- dependence of the tolerance of autotrophic and heterotrophic periphyton communities to copper and diuron. Aquat Toxicol 98: $165-177$

Tlili A, Corcoll N, Bonet B, Morin S, Montuelle B, Berard A, Guasch H (2011) In situ spatio-temporal changes in pollution-induced community tolerance to zinc in autotrophic and heterotrophic periphyton communities. Ecotoxicology 20: 1823-1839

Tlili A, Montuelle B (2011) Microbial pollution-induced community tolerance. Tolerance to Environmental Contaminants. CRCpress: 85-108

Tobar, JL, Boubeta-Novas J, Arredondo-Vega BO, FábregasJ (1993) Incorporación de cobre en la microalga marina Tetraselmis suecica en función de su concentración en el medio. Actas III Congreso Latinoamericano de Ficología 


\begin{tabular}{|c|c|c|c|}
\hline & & $\mathbf{E C}_{50}$ & $\mathrm{EC}_{10}$ \\
\hline & $2 h$ & $0.21 \pm 0.07$ & $0.02 \pm 0.02$ \\
\hline \multirow[t]{2}{*}{ D4 } & $4 h$ & $0.08 \pm 0.02$ & $0.01 \pm 0.01$ \\
\hline & $6 h$ & $0.09 \pm 0.02$ & $0.02 \pm 0.02$ \\
\hline \multirow{3}{*}{ D3 } & $2 h$ & $0.11 \pm 0.02$ & $0.03 \pm 0.02(a b)$ \\
\hline & $4 h$ & $0.10 \pm 0.03$ & $0.01 \pm 0.01(b)$ \\
\hline & $6 \mathrm{~h}$ & $0.13 \pm 0.02$ & $0.05 \pm 0.02(\mathrm{a})$ \\
\hline \multirow{3}{*}{ D2 } & $2 h$ & $0.27 \pm 0.05$ & $0.11 \pm 0.05$ \\
\hline & $4 h$ & $0.30 \pm 0.09$ & $0.05 \pm 0.02$ \\
\hline & $6 \mathrm{~h}$ & $0.30 \pm 0.06$ & $0.06 \pm 0.02$ \\
\hline \multirow{3}{*}{ D1 } & $2 h$ & $0.76 \pm 0.24$ & $0.13 \pm 0.06$ \\
\hline & $4 h$ & $0.92 \pm 0.31$ & $0.18 \pm 0.09$ \\
\hline & $6 \mathrm{~h}$ & $1.23 \pm 0.52$ & $0.19 \pm 0.08$ \\
\hline
\end{tabular}

485

486

487

488

489

490

491

492

493

494

495

496

497

498

499

500

501 

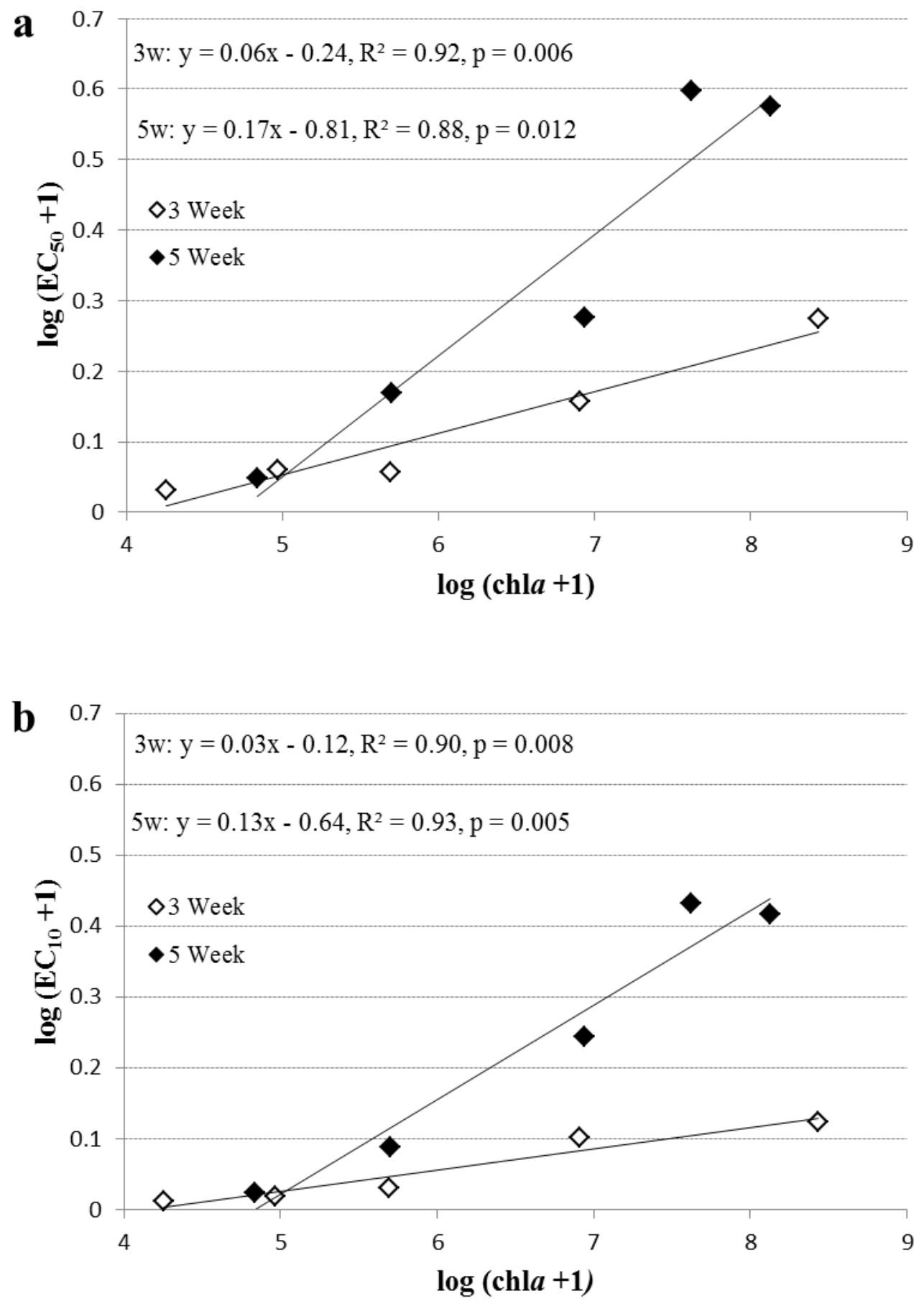

Fig 1. Linear relationship between mean chla concentrations in periphyton suspension $(\mu \mathrm{g} / \mathrm{L})$ and (a) mean $\mathrm{EC}_{50}$ and (b) mean $\mathrm{EC}_{10}(\mathrm{mg} \mathrm{Cu} / \mathrm{L})$ during toxicity tests performed with a 3-and 5-week periphyton after $2 \mathrm{~h}$ of incubation. 
a

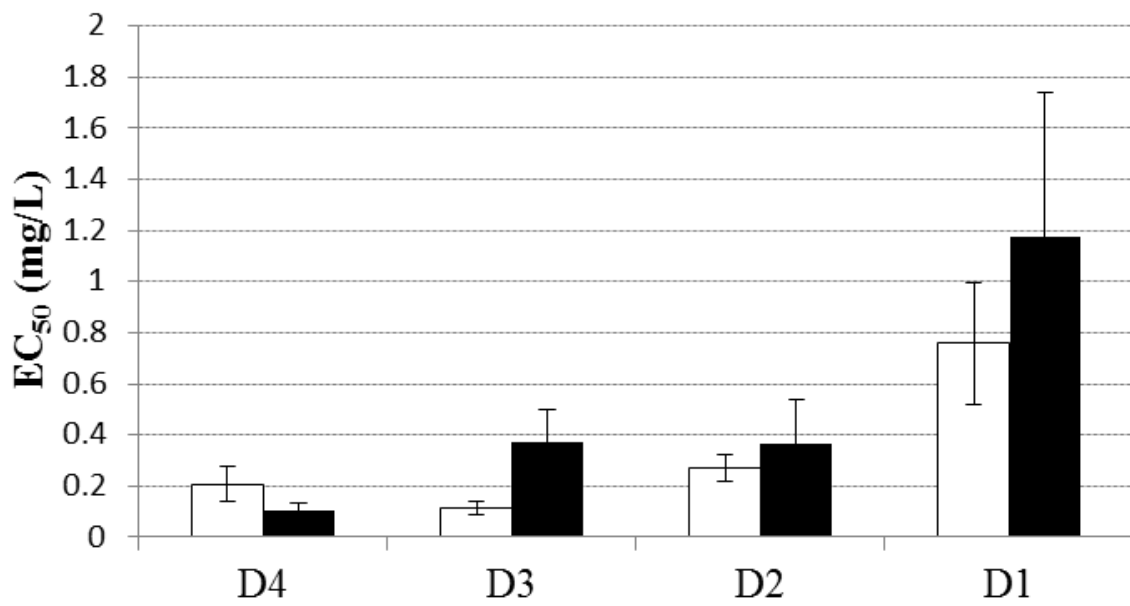

$\square$ Week 3

- Week 5

510

b

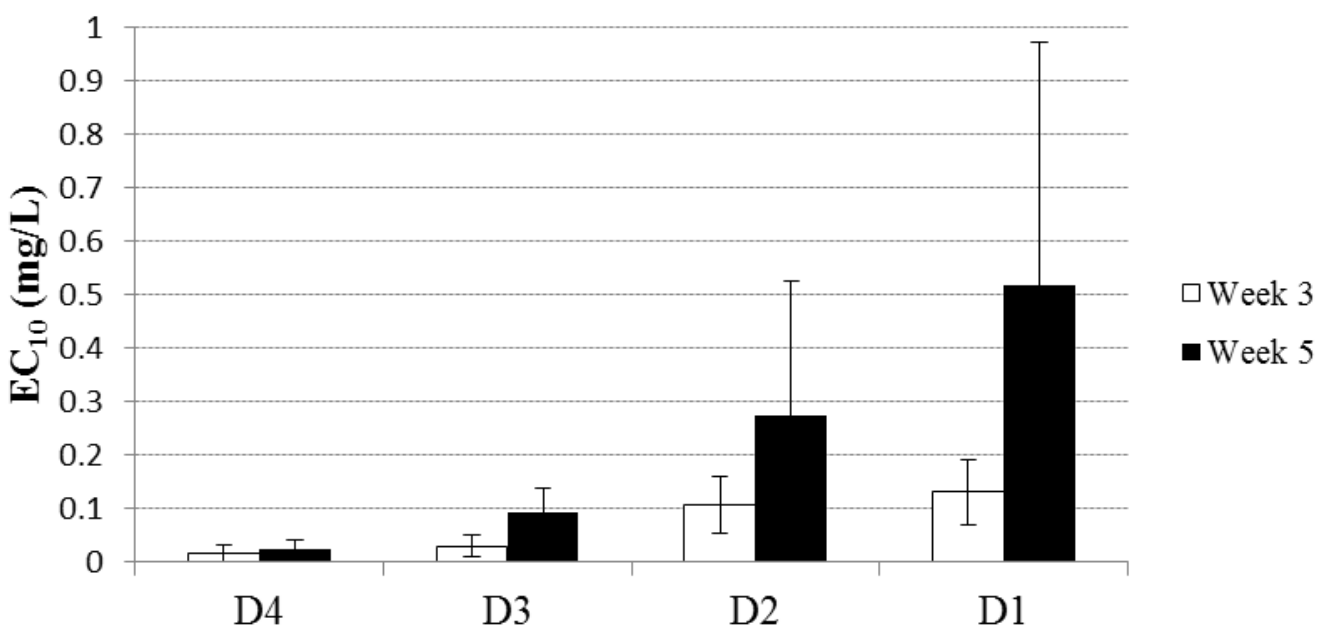

512 Fig 2. Mean ( \pm s.d.) for (a) $\mathrm{EC}_{50}$ and (b) $\mathrm{EC}_{10}(\mathrm{mg} \mathrm{Cu} / \mathrm{L})$ for periphyton suspension concentrations, ranging from 513 about $400 \mu \mathrm{g} \mathrm{chla/L}$ (D4) to about $7000 \mu \mathrm{g}$ chla/L (D1) during toxicity tests performed with a 3- and 5-week 514 periphyton after $2 \mathrm{~h}$ of incubation, $n=3$. 


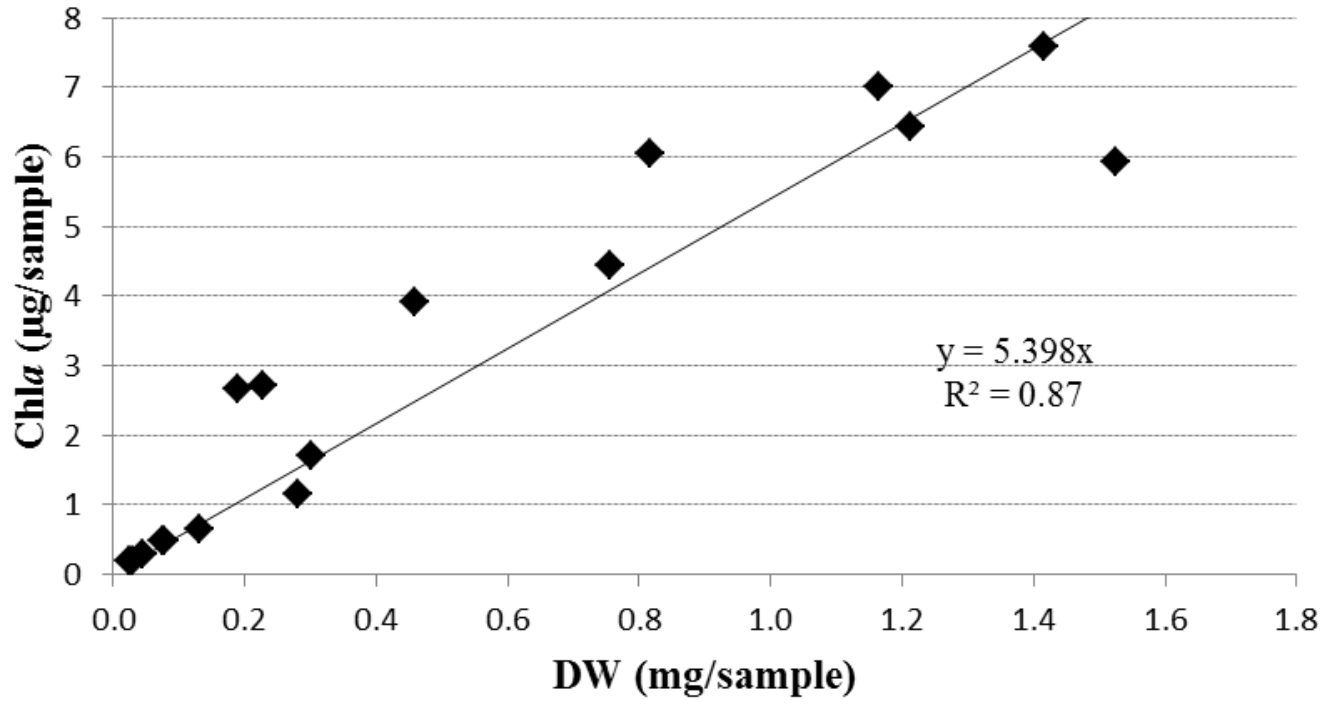

516 Fig 3. Linear relationship between chla ( $\mu \mathrm{g} / \mathrm{sample})$ and DW (mg/sample) obtained with 5-week periphyton. 517 chla concentrations and dry weight are in relation to the total volume of the periphyton suspension used during 518 toxicity testing.

519 